\title{
Assessing fish community structure at two different coral reef depths around Seribu Islands, Jakarta
}

(Penilaian struktur komunitas ikan terumbu pada dua kedalaman terumbu karang berbeda sekitar Kepulauan Seribu, Jakarta)

\section{Karizma Fahlevy ${ }^{1,2}$, Firsta Kusuma Yudha ${ }^{1,3}$, Wedi Andika ${ }^{1,2}$, Ahmad Eko Suprianto $^{1,2}$, Nadya Jeny Irianda ${ }^{1,2}$,Mas Irfanto ${ }^{1,4}$, Beginer Subhan ${ }^{2}$, Hawis Madduppa $^{2}$}

\footnotetext{
${ }^{1}$ Fisheries Diving Club, Bogor Agricultural University, Bogor 16880, Indonesia ${ }^{2}$ Department of Marine Science and Technology, Bogor Agricultural University, Bogor 16880, Indonesia

${ }^{3}$ Department of Aquatic Resources Management, Bogor Agricultural University, Bogor 16880 , Indonesia

${ }^{4}$ Department of Aquaculture, Bogor Agricultural University, Bogor 16880, Indonesia e-mail : karizmafahlevy@yahoo.com
}

\begin{abstract}
Coral reefs structure play important roles for reef fish assemblages. Coral coverage and reef fish abundance are associated with the positive relationship. However, the relationship between reef fish abundance and composition and depth variation around Pramuka Island is poorly known. This study was carried out to investigate the biodiversity and the trophic level of fish communities between two different depths (3 and $10 \mathrm{~m}$ ) around Pramuka Island regions (Pramuka Island and Sekati Island). The hard coral at the depth of $10 \mathrm{~m}$ within both study sites in Pramuka island held significantly higher percent cover than the depth of $3 \mathrm{~m}$ except in Dock 2 A total of 2620 individual fishes were counted, belonging to 58 species and 13 families. The fish community in 3 and 10 depth was dominated by omnivorous fishes. The multivariate analysis of fish abundance using the Bray Curtis similarity index and non-metric multidimensional scaling (NMDS) clearly showed the clustering of two different depths. The NMDS results showed that at the depth of $10 \mathrm{~m}$ are more clustered than $3 \mathrm{~m}$ depth. The present study results showed that the biodiversity of reef fishes around Pramuka Island seemed to be linked to the hard coral condition and depth.
\end{abstract}

Keywords: Coral, Depth, Reef fishes, Trophic level

\section{Introduction}

The complexity of coral reefs structure play important roles in reef fish assemblages (Alvarez-Filip 2011) and contribute to a differences ecosystem services that value to humans (Lane et al., 2013). Several studies have shown the relationships between various coral and the species richness of fishes. Komyakova et al., (2010) were reported positive correlations between coral and reef fish abundance. Corals are threatened by local disturbances, coral disease (Subhan et al., 2011), coral mining (Subhan et al., 2008) and environmental condition (Friedlander et al., 2017). Seribu Islands located in front of Jakarta and belong to one of the marine national parks in Indonesia (Fahlevy et al., 2017). However, the existences of coral reef in Seribu Islands are threatened. Environmental pressures (e.g pollution) from Jakarta increases the degradation of marine biodiversity in Seribu Islands (Baum et al., 2015). 
Degradation of coral structures giving a negative impact on reef fish communities across Seribu Islands (Madduppa et al., 2013). The depletion of reef fishes increased accordingly with the degradation of corals (Burgess et al., 2010) and often associated with over or destructive fishing activities (Robinson et al., 2014). Destructive fishing activities still occur in Seribu Islands (Santoso, 2010).

Management of Kepulauan Seribu Marine National Park is still ineffective (Fauzi and Buchary, 2002). Management and regulation of the area are needed for marine biodiversity protection (Harter et al., 2009). A challenge for completing the fishing regulation is to determine how topography and depth use interact to influence the reef fish structures and ecosystem services (Luiz et al., 2015). The present study aimed to assess reef fish community structures and examine the influence of depth on the fish communities around Pramuka Island regions (Pramuka Island and Sekati Island), Seribu Islands

\section{Materials and Methods \\ 2.1 Study sites}

The study was conducted during 14-19 December 2014 around Pramuka island regions (Figure 1). Two different depths $(3$ and $10 \mathrm{~m}$ ) for each sampling site at reef slope were selected. Pramuka island is one of the main islands located in Kepulauan Seribu (Seribu Islands) Marine National Park, Jakarta (Baum et al., 2015).

\subsection{Data collection}

Coral structures were assessed and identified to genus level at each location using three replicate $20 \mathrm{~m}$ line-intercept transects parallels with shoreline (English et al., 1997) separated by at least $5 \mathrm{~m}$. Fish community composition was assessed along the same transects as corals structure using underwater visual census (English et al., 1997) which are divided into two categories of fish count (real count and estimate). Major fish counts were mostly done by estimation (semi-quantitative), while indicator and target fishes were mostly done by real count. Reef fishes were counted and identified to species and recorded within $2.5 \mathrm{~m}$ of each side of the transect line by slowly swimming and wait for at least 5 minutes before the beginning of data recording along the line at a constant speed (Madduppa et al., 2013). The censused fish were then classified into three major groups (target, indicator, and major fish) according to English et al., (1997). The trophic level for each species confirmed and classified using FishBase (Froese and Pauly 2010). 


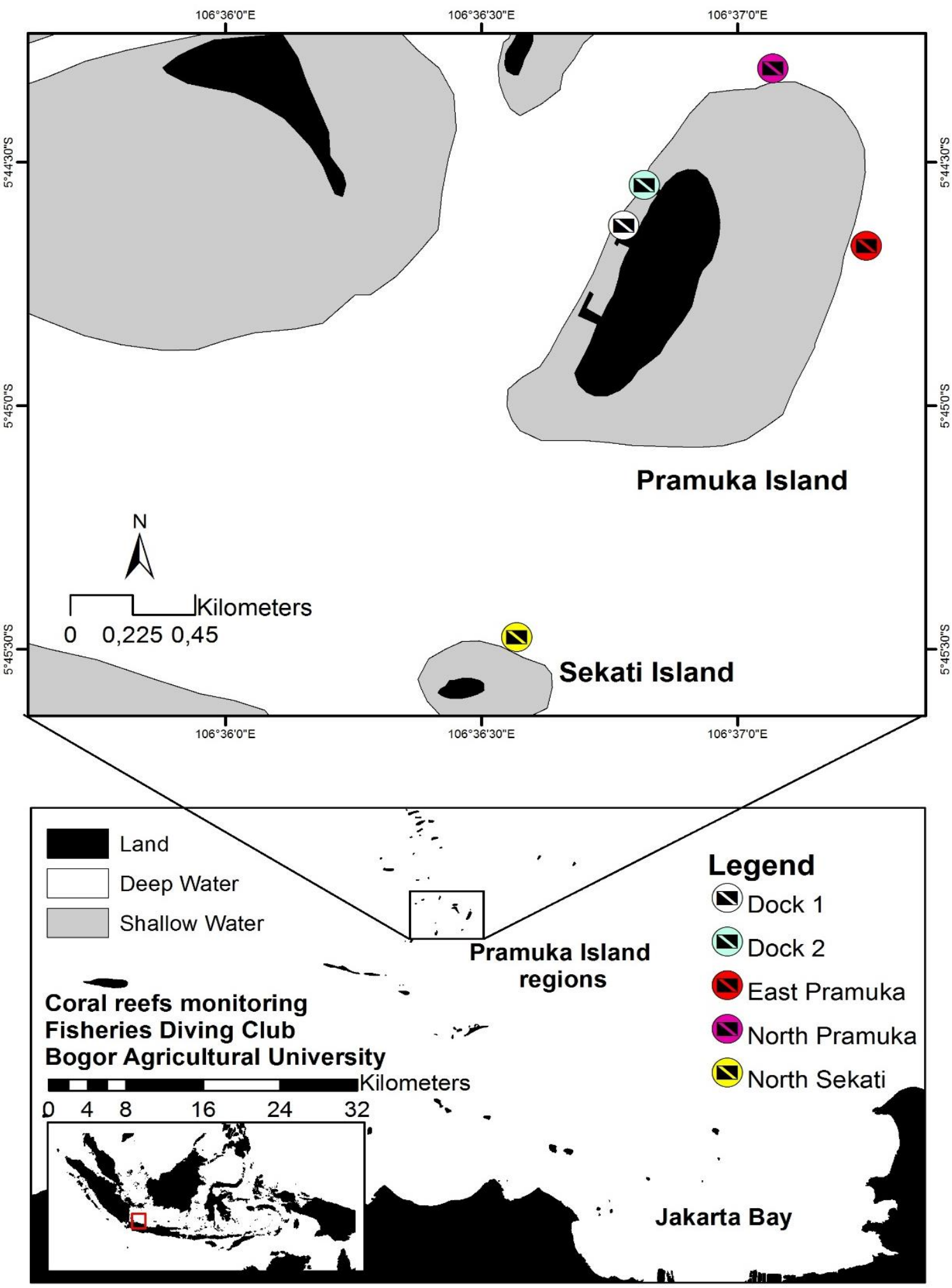

Figure 1. Location of the Pramuka Island regions, north of Jakarta, Java Island, Indonesia. The map below shows the position of Pramuka Island regions relative to Jakarta. The location within Indonesia is shown in the inset on the lower left 


\subsection{Data analysis}

Percentage of the hard coral cover was estimated using English et al., (1997):

$$
\text { Percent Cover (\%) }=\frac{A}{B} X 100 \%
$$

$$
\begin{array}{ll}
\mathrm{A} & =\text { Length of category } \\
\mathrm{B} & =\text { Length of transect }
\end{array}
$$

Shannon-Wiener diversity index H’ (ln basis) were calculated (Magurran 1988)

$$
H^{\prime}=-\sum p_{i} \ln \left(p_{i}\right)
$$

$$
\begin{aligned}
& H^{\prime} \quad=\text { Community Shannon-Wiener diversity index } \\
& p_{i} \quad=\text { Proportion of individuals belonging to the } i^{\text {th }}
\end{aligned}
$$

Two-way analysis of variance (ANOVA) was used to test for significant differences in abundance, species richness and community diversity among study sites and two different depths using Ms. Excel 2013. Multivariate analysis of reef fish community was conducted using PRIMER 7. Relative abundance was square root transformed to reduce the disparity between the abundant and uncommon species (Harter et al., 2009). Similarity matrix constructed using Bray-Curtis Similarity (Benfield et al., 2008).

Multivariate analysis of similarity (ANOSIM) based on both the entire fish community was used to determine differences between two depths ( 3 and $10 \mathrm{~m}$ ). SIMPER (similarity percentages) was used to examine reef fish assemblages that contributed to $80 \%$ of the fish composition of each depth. Prior to analyses, species in which found only in one transect were observed, species contributing $<5 \%$ in SIMPER analysis at both of depths, and species comprising $<1 \%$ of the total abundance of fish were deleted to minimize uncommon species disrupting the cluster analysis. Non-metric Multidimensional Scaling (MDS) and similarity were used to visualize the differences in fish communities of the two different habitats (3 and $10 \mathrm{~m}$ ) (Madduppa et al., 2012a; Madduppa et al., 2012b).

\section{Results and Discussion}

\section{1 Results}

\subsubsection{Hard coral cover}

In all study sites except Dock 2, coral cover was usually the highest in the depth of $3 \mathrm{~m}$ rather than the depth of $10 \mathrm{~m}$ (Table 1). Study site that showed signs of damage and had less living hard coral cover $(3.73 \pm 1.43 \%)$ was located in Dock 2 at the depth of $10 \mathrm{~m}$. The North Sekati exhibited the highest cover at the depth of $3 \mathrm{~m}(36.27 \pm$ $16.30 \%)$, followed by North Pramuka $(18.07 \pm 2.53 \%)$, Dock $2(11.90 \pm 4.08 \%)$, East Pramuka $(10.07 \pm 4.89 \%)$, and Dock $1(8.47 \pm 3.98 \%)$. On the depth of $10 \mathrm{~m}$ around Pramuka Island, the four consistently higher coral cover over all sites were East Pramuka $(24.57 \pm 11.89 \%)$, North Pramuka $(22.98 \pm 16.05 \%)$, North Sekati $(18.65 \pm$ $3.43 \%)$, and Dock $1(12.02 \pm 3.04 \%)$. 
Table. 1 Relative percentage of hard coral cover (mean \pm SE) in the different study sites and depth

\begin{tabular}{lcc}
\hline \multirow{2}{*}{ Study Site } & \multicolumn{2}{c}{ Depth } \\
\cline { 2 - 3 } & $3 \mathrm{~m}(\% \pm \mathrm{SE})$ & $10 \mathrm{~m}(\% \pm \mathrm{SE})$ \\
\hline Dock 1 & $8.47 \pm 3.98$ & $12.02 \pm 3.04$ \\
Dock 2 & $11.90 \pm 4.08$ & $3.73 \pm 1.43$ \\
East Pramuka & $10.07 \pm 4.89$ & $24.57 \pm 11.89$ \\
North Pramuka & $18.07 \pm 2.53$ & $22.98 \pm 16.05$ \\
North Sekati & $36.27 \pm 16.30$ & $18.65 \pm 3.43$ \\
\hline
\end{tabular}

\subsubsection{Fish community structure}

A total of 2620 individuals from 58 species of fish belonging to 13 families were counted in this study (Table. 2). Pomacentridae was the most dominant family in terms of abundance followed by Labridae. Pomacentrus alexanderae was the most abundant species followed by Pomacentrus simsiang and Chromis viridis. Chromis virdis were not widely found but when its found, they occurred in large schools of over 50 up to 125 individuals.

No significant differences in fish abundance and diversity were found between the study sites and depths, while species richness significantly differed in the study sites, and the effect of sites on abundance and species richness differed between depths (Table 3). The average fish abundance, the average species richness, and the ShannonWiener diversity indices of fish communities are shown in Figure 2. North Sekati had the higher value of fish abundance, species richness, and species diversity. The lowest fish abundance found in East Pramuka at the depth of $3 \mathrm{~m}$, while North Sekati at the depth of $3 \mathrm{~m}$ is the most abundant.

The fish abundance range from $35 \pm 13.45$ (East Pramuka) to $156.67 \pm 11.72$ ind $/ 100 \mathrm{~m}^{2}$ (North Sekati). Similar pattern was also found for the species richness which ranged between $7.67 \pm 1.67$ (East Pramuka) and $23 \pm 2.64$ species $/ 100 \mathrm{~m}^{2}$ (North Sekati). Among the five study sites, the value of diversity indices $\left(\mathrm{H}^{\prime}\right)$ of North Pramuka at the depth of $10 \mathrm{~m}$ was the lowest, which ranged between $1.35 \pm 0.11$ (North Pramuka) and $2.05 \pm 0.25$ (North Sekati).

Table 2. Total number and trophic level of fish species at each study sites (* means estimated count)

Family

Species

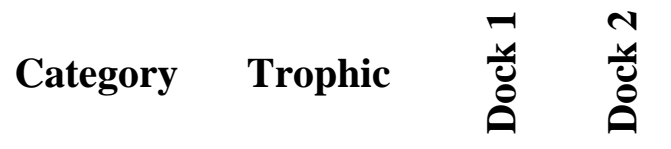

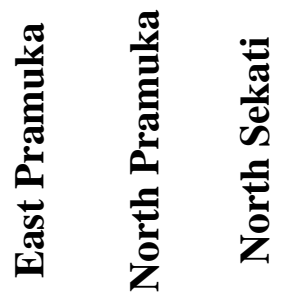

\section{Apogonidae}

Apogon compressus

Balistidae

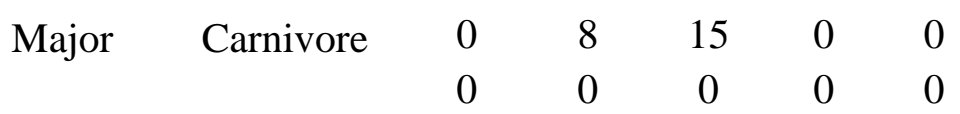


ISSN 2620-570X

JuRnal Ilmu Kelautan KePulauan, 1 (1) ; 15 - 29, Juni 2018

Rhinecanthus verrucosus

\section{Caesionidae}

Caesio cuning

Caesio teres

Chaetodontidae

Chaetodon octofasciatus

Chelmon rostratus

\section{Labridae}

Bodianus mesothorax

Cheilinus chlorourus

Cheilinus fasciatus

Choerodon anchorago

Cirrhilabrus cyanopleura

Halichoeres chloropterus

Halichoeres hortulanus

Halichoeres leucurus

Halichoeres melanurus

Halichoeres richmondi

Halichoeres vrolikii

Labroides dimidiatus

Thalassoma lunare

Lutjanus biguttatus

\section{Nemipteridae}

Scolopsis bilineata

Scolopsis lineata

Scolopsis margaritifer

Scolopsis trilineata

\section{Lutjanidae}

$\begin{array}{ccccccc}\text { Target } & \text { Omnivore } & 0 & 0 & 0 & 1 & 0 \\ & & & & & & \\ \text { Target } & \text { Carnivore } & 0 & 0 & 2 & 2 & 8 \\ \text { Target } & \text { Carnivore } & 9 & 0 & 3 & 5 & 29\end{array}$

$\begin{array}{lllllll}\text { Indicator } & \text { Corallivore } & 9 & 11 & 4 & 16 & 22\end{array}$

Indicator Corallivore $11 \quad 0 \quad 0 \begin{array}{llll}0 & 0 & 0\end{array}$

\begin{tabular}{lcccccc} 
Target & Carnivore & 0 & 3 & 3 & 0 & 2 \\
Target & Carnivore & 0 & 0 & 0 & 0 & 1 \\
Target & Carnivore & 25 & 5 & 4 & 49 & 8 \\
Target & Carnivore & 1 & 2 & 2 & 8 & 9 \\
Major & Planktivore & 15 & 15 & 6 & 0 & 62 \\
Major & Carnivore & 2 & 0 & 0 & 0 & 6 \\
Target & Carnivore & 0 & 0 & 0 & 4 & 16 \\
Major & Omnivore & 10 & 2 & 12 & 9 & 26 \\
Target & Omnivore & 8 & 3 & 2 & 0 & 11 \\
Major & Carnivore & 2 & 1 & 0 & 0 & 14 \\
Major & Omnivore & 0 & 0 & 0 & 0 & 3 \\
Major & Carnivore & 9 & 2 & 3 & 4 & 0 \\
Major & Omnivore & 0 & 5 & 4 & 24 & 21 \\
& & & & & & \\
Target & Carnivore & 0 & 0 & 0 & 0 & 1 \\
& & & & & & \\
Target & Carnivore & 0 & 2 & 0 & 4 & 22 \\
Target & Carnivore & 0 & 0 & 4 & 5 & 16 \\
Target & Carnivore & 0 & 0 & 8 & 0 & 4 \\
Target & Carnivore & 0 & 0 & 1 & 0 & 4 \\
\hline & & & & & &
\end{tabular}

\section{Ostraciidae}

Ostracion cubicus

Major

Carnivore

0

0

0

0

1

Major

Omnivore

0

Major

Herbivore

Major

Omnivore

Major

Major

Major

Major

Major

Major
Omnivore

Omnivore

Omnivore

Omnivore

Omnivore

Omnivore

0

$\begin{array}{llll}0 & 0 & 0 & 7\end{array}$

$\begin{array}{llll}0 & 0 & 0 & 2\end{array}$

Amblyglyphidodon leucogaster

Amphiprion ocellaris

$\begin{array}{ccccc}3 & 0 & 0 & 0 & 0 \\ 4 & 5 & 33 & 11 & 25 \\ 8 & 0 & 0 & 2 & 10 \\ 0 & 0 & 1 & 0 & 0 \\ 12 & 19 & 8 & 27 & 24 \\ 0 & 0 & 0 & 4 & 0 \\ 0 & 0 & 0 & 0 & 3\end{array}$


ISSN 2620-570X

JuRnal Ilmu Kelautan Kepulauan, 1 (1) ; 15 - 29, Juni 2018

\begin{tabular}{|c|c|c|c|c|c|c|c|}
\hline Chromis amboinensis & Major & Omnivore & 0 & 0 & 0 & 0 & 50 \\
\hline Chromis lepidolepis & Major & Planktivore & 0 & $100^{*}$ & 0 & 0 & 0 \\
\hline Chromis viridis & Major & Omnivore & 0 & $125^{*}$ & 0 & 0 & 50 \\
\hline Dascyllus trimaculatus & Major & Omnivore & 12 & 0 & 0 & 0 & 0 \\
\hline Dischistodus perspicillatus & Major & Herbivore & 0 & 17 & 10 & 0 & 0 \\
\hline Dischistodus prosopotaenia & Major & Herbivore & 18 & 29 & 16 & 13 & 6 \\
\hline Neoglyphidodon melas & Major & Omnivore & 2 & 6 & 3 & 12 & 19 \\
\hline Neoglyphidodon oxyodon & Major & Omnivore & 0 & 0 & 0 & 0 & 11 \\
\hline Neoglyphidodon thoracotaeniatus & Major & Omnivore & 0 & 0 & 0 & 0 & 10 \\
\hline Pomacentrus alexanderae & Major & Omnivore & $204 *$ & 98 & $168 *$ & 122 & 58 \\
\hline Pomacentrus brachialis & Major & Omnivore & 0 & 6 & 0 & 19 & 6 \\
\hline Pomacentrus burroughi & Major & Herbivore & 11 & 0 & 0 & 10 & 6 \\
\hline Pomacentrus lepidogenys & Major & Planktivore & 0 & 0 & 0 & 1 & 0 \\
\hline Pomacentrus moluccensis & Major & Omnivore & 7 & 6 & 4 & 14 & 40 \\
\hline Pomacentrus nagasakiensis & Major & Omnivore & 9 & 6 & 6 & 31 & 17 \\
\hline Pomacentrus philippinus & Major & Omnivore & 2 & 4 & 0 & 54 & 31 \\
\hline Pomacentrus simsiang & Major & Omnivore & 20 & 27 & 39 & 58 & 38 \\
\hline Pomacentrus smithi & Major & Omnivore & 8 & 32 & 32 & 6 & 21 \\
\hline \multicolumn{8}{|l|}{ Scaridae } \\
\hline Chlorurus capistratoides & Target & Herbivore & 1 & 4 & 0 & 2 & 4 \\
\hline \multicolumn{8}{|l|}{ Serranidae } \\
\hline Cephalopholis boenak & Target & Carnivore & 2 & 1 & 1 & 1 & 3 \\
\hline Cephalopholis microprion & Target & Carnivore & 0 & 0 & 0 & 0 & 3 \\
\hline Cephalopholis miniata & Target & Carnivore & 0 & 0 & 0 & 0 & 1 \\
\hline \multicolumn{8}{|l|}{ Siganidae } \\
\hline Siganus guttatus & Target & Herbivore & 0 & 8 & 0 & 0 & 0 \\
\hline Siganus virgatus & Target & Herbivore & 11 & 0 & 0 & 0 & 0 \\
\hline
\end{tabular}

The most trophic categories among the five study sites was omnivore at the depth of $3 \mathrm{~m}$. Similar things was found at the depth of $10 \mathrm{~m}$, omnivorous fishes dominated in all sites. Therefore, it could be attributed to the result of reef fish abundance. Almost of the entire fish community composition differed significantly between the study sites and a significant effect was found between the depths (Table 4). The SIMPER analyses revealed that three species settled at the depth of $3 \mathrm{~m}$, Pomacentrus alexanderae, Pomacentrus simsiang, Dischistodus perspicillatus (Pomacentridae), and the three species settled at the depth of $10 \mathrm{~m}$, Pomacentrus alexanderae, Dischistodus prosopotaenia, Pomacentrus simsiang (Pomacentridae) are shown in Table 5. 
Table 3. Result of repeated-measures ANOVA for abundance, species richness of reef fish $(* p<0.05, n . s$. not significant)

\begin{tabular}{lllccc}
\hline Variable & Factor & $F$ & $F$ crit & $d f$ & $p$ \\
\hline Abundance & Site & 2.18 & 2.87 & 4 & n.s \\
& Depth & 0.99 & 4.35 & 1 & n.s \\
& Site*Depth & 4.52 & 2.87 & 4 & $*$ \\
Species Richness & Site & 7.99 & 2.87 & 4 & $*$ \\
& Depth & 0.18 & 4.35 & 1 & n.s \\
Shanon-Wiener index (H') & Site*Depth & 6.39 & 2.87 & 4 & $*$ \\
& Site & 0.98 & 2.87 & 4 & n.s \\
& Depth & 0.02 & 4.35 & 1 & n.s \\
& Site*Depth & 1.59 & 2.87 & 4 & n.s \\
\hline
\end{tabular}

The significant differences in fish communities between two depths in terms of species abundance detected by the ANOSIM (Table 4). The clusters were visible in the MDS plots (Figure 4). The community samples from the $3 \mathrm{~m}$ depth clearly separate, while the $10 \mathrm{~m}$ depth are clustered more closely together.

\subsection{Discussion}

\subsubsection{Hard coral cover}

The results in Table 1 are shown the percentage of coral cover at the study sites. The hard coral cover percentage was very low, it was ranged from $3 \%-35 \%$. Therefore, it indicated the coral cover condition does not play a role in the reef fishes individual abundances but more dominantly influenced by the form of coral growth in the study sites. Considering the ship activities very intense in the docks, it has been observed damaging (Dinsdale \& Harriot, 2004) and affect the corals (McKenna \& Etnoyer, 2010). Ship traffic in Pramuka is high. Local ship, dump ship, freighters, government ship, cruise ships and yachts transit over the docks. Anchor damage are known to cause extensive physical damage to coral. Several study sites having low hard coral cover, human impacts are evident from habitation, tourism and fishing activity and have been identified as local threats. Several anthropogenic factor cause damage to corals (Dinsdale and Harriot, 2004) such as destructive fishing (Fenner, 2012) and coral mining (Hariri, 2012). Local fishermen around Pramuka Island are still using muroami to collect fish (Zamani et al., 2011) and Iskandar (2011) has reported several fishermen in Seribu islands are still using muroami. Muroami is the destructive fishing tools causing the damage on corals (Graham et al., 2011). The loss of coral cover in IndoPacific have been underestimated (Bruno \& Selig 2007). Coral reefs near human habitation are relatively fragile with regards to impacts from local activities (Riegl et al., 2012) and local dependence on coral is high (Pendleton et al., 2016). Baum et al., (2015) has assessed the local and regional pollution affected the benthic communities in Seribu Islands. Other potential damages on corals also comes from recreational diving activities around Pramuka island. Recreational and tourism activities physically damage the coral (Lane et al., 2013). Environmental condition also threatened the corals (Setyawan et al.,, 2011, Zamani and Madduppa, 2011), although several corals have different resistant from the environmental stressors (McClanahan et al., 2004). There are important roles of specific corals on reef fish existence (Madduppa et al., 2014) and 
the corals influence reef fish assemblages (Benfield et al., 2008; Madduppa et al., 2012b). The important things in the present study, the abundance of several species of fish such as Pomacentrus alexanderae and several other species of Pomacentrus $s p$./Chromis sp. are strongly affected by the presence of certain coral species such as the Chromis viridis fish species associated with coral species of Porites cylindrica (Nanami et al, 2005; Mesmer et All, 2011) and Pomacentrus alexaderae with Acropora spp (Nanami et al, 2005; Randall et al, 1990).. The structure of coral reefs particularly important for critical resources in their association with reef fishes (Komyakova et al.,, 2013; Madduppa et al., 2012b).

\subsubsection{Fish community structure}

Previous study also observed the most diverse families in Seribu islands were Pomacentridae and Labridae (Estradivari et al., 2007; Madduppa et al., 2013), those are the most dominantly found in reef fish community (Edrus \& Abrar, 2016). Reef fish community were observed at small island ecosystem in Kepulauan Seribu National Park (TnKPS). Pomacentrus alexanderae, and Chromis viridis are classified as major reef fish in functional group which is generally found in large quantities (Sjafrie, 2009; Madduppa et al., 2012a) while Pomacentrus simsiang were significantly found at the reefs where the island was present (Dixon et al.,, 2011). The corals influence reef fish assemblages (Benfield et al., 2008; Madduppa et al., 2012b). Previous study in Japan, the coral habitat held significantly higher species richness and abundance of reef fish assemblages (Nakamura et al., 2013). Seasonal migration of reef fish also affect the composition of some species (Madduppa et al., 2012b).

Study sites were influenced reef fish species richness. Each study sites have the different percentage of hard coral cover (Table 1), indicating of how the study sites affect the species richness. The previous study indicates positive correlations between fish species richness and location with different of percentage coral cover (Gratwicke \& Speight, 2005). Pomacentridae (damselfishes) was the most dominant family in terms of abundance. Litsios et al., (2012) were classified the damselfishes into three main class, herbivorous benthic feeders, omnivorous group, and pelagic feeders mainly eat planktonic prey, but damselfishes usually considered as omnivorous fishes. Therefore, it causes the percentage of reef fishes among five study sites was dominated by omnivorous fishes.
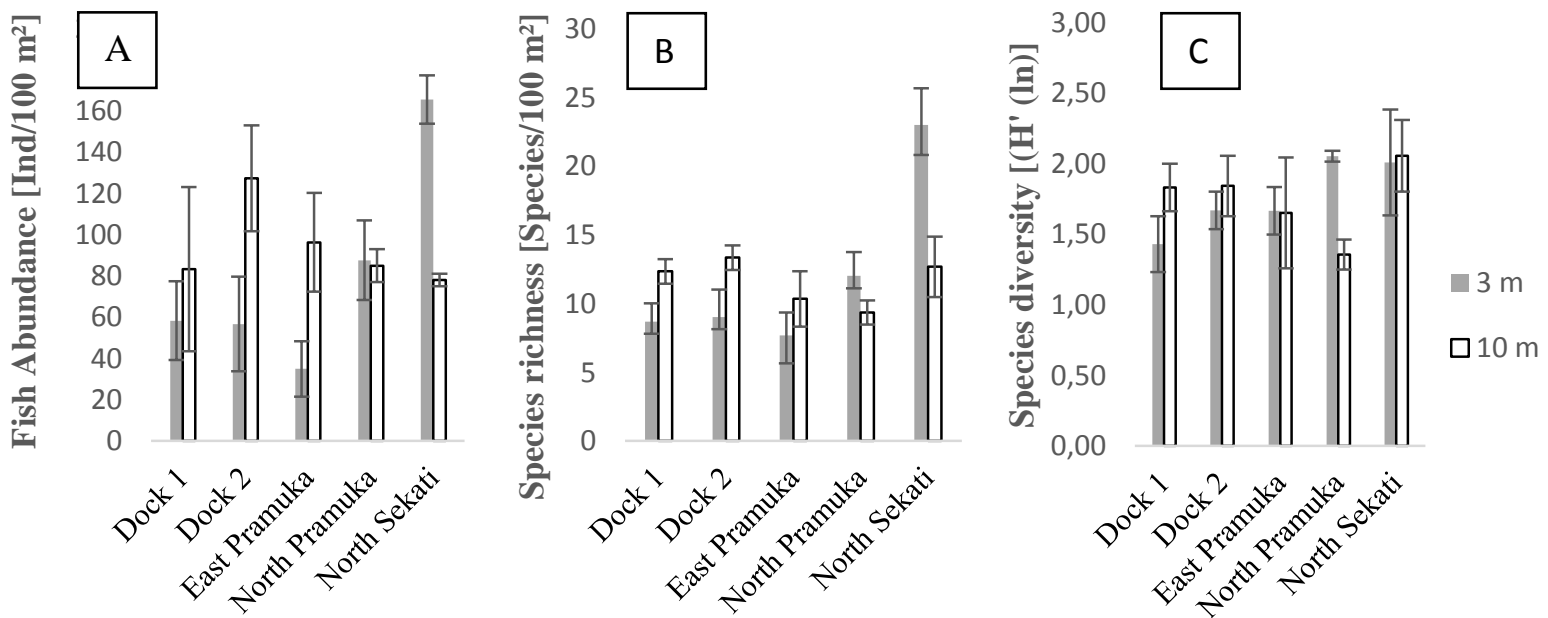

Figure 2. Average value of (a) fish abundance, (b) species richness and (c) species diversity (ln basis) of reef fish assemblages at the study sites 

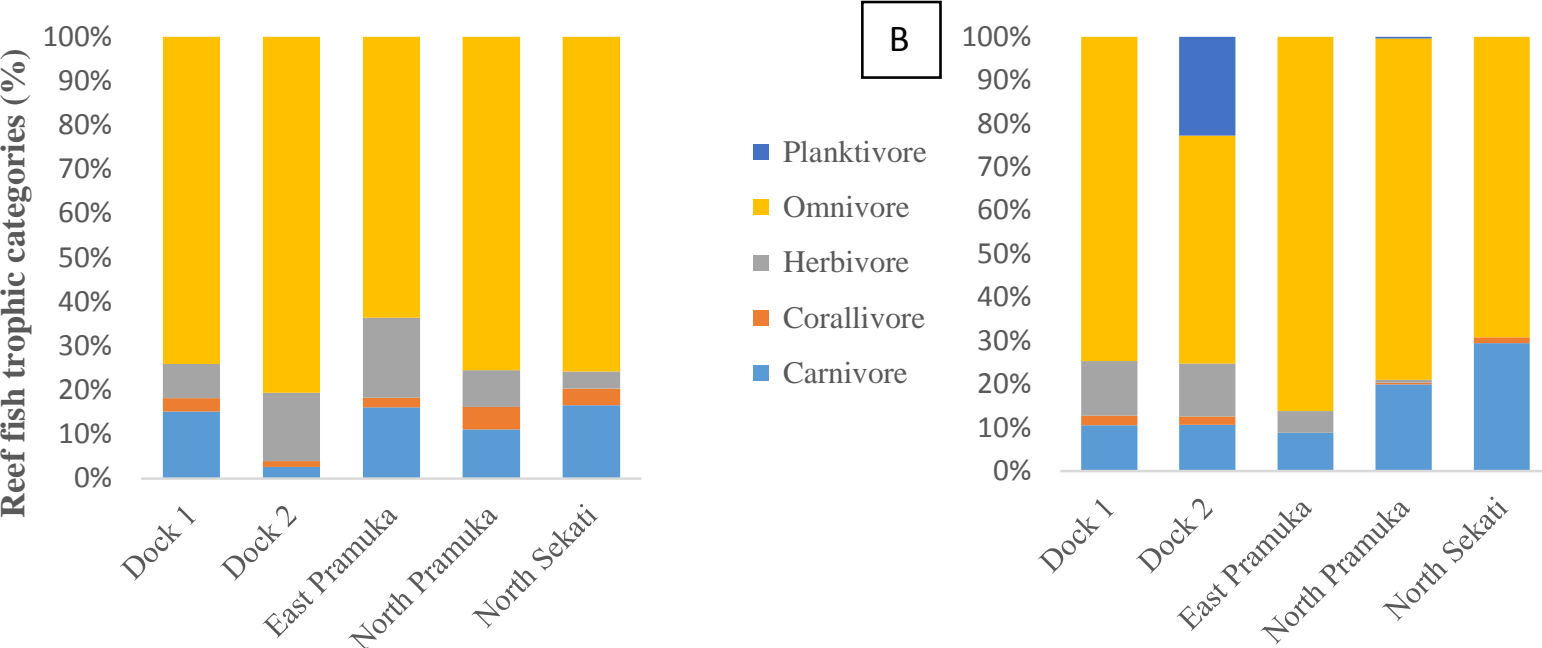

Figure 3. Percentage of reef fishes at the sampling sites, and (a) depth of $3 \mathrm{~m}$, (b) depth of $10 \mathrm{~m}$ based on trophic categories

\subsubsection{Spatial variation of the fish community from different depths}

Both of the three species at the two different depths are from the Pomacentridae family which were found at the depth of $3 \mathrm{~m}$ and $10 \mathrm{~m}$ in Seribu Islands (Madduppa et al., 2013).

Table 4. Result of a crossed two-way ANOSIM within sites based on abundance of all species $(* p<0.05$, n.s. not significant)

\begin{tabular}{lllrl}
\hline Relative Abundance & & & \\
\hline Test & Factor & Test pairs & $\rho$ & $p(\rho)$ \\
\hline Global Pairwise & Site & Dock 1, Dock 2 & 0.5 & $*$ \\
& & Dock 1, East Pramuka & 0.574 & $*$ \\
& & 0.63 & $*$ \\
& & Dock 1, North Pramuka & 0.796 & $*$ \\
& & Dock 1, North Sekati & 0.13 & n.s \\
& & Dock 2, East Pramuka & 0.704 & $*$ \\
& & Dock 2, North Pramuka & 0.778 & $*$ \\
& & Dock 2, North Sekati & 0.87 & $*$ \\
& & East Pramuka, North Pramuka & 0.926 & $*$ \\
Global Pairwise & Depth & East Pramuka, North Sekati & 0.613 & $*$ \\
\hline
\end{tabular}

Although the result from the univariate community parameters could not differentiate between the most of study sites and depths, the clear difference was shown in the multivariate analysis of the reef fish community and able to detect the differences between the composition of the coral reef fish community associated with the difference of depth based on fish abundance. 
Table 5. Composition of 10 most high species contribution within each sampling site using SIMPER (Similarity Percentages - Species Contribution)

\begin{tabular}{lcccc}
\hline Species per depth & $\begin{array}{l}\text { Av. } \\
\text { Abundance }\end{array}$ & $\begin{array}{l}\text { Av. } \\
\text { Similarity }\end{array}$ & \%Contribution & \%Cumulative \\
\hline 3 m, average similarity: 30,97 & & & & \\
Pomacentrus alexanderae & 1,93 & 4,36 & 14,07 & 14,07 \\
Pomacentrus simsiang & 1,80 & 3,10 & 10,01 & 24,08 \\
Dischistodus perspicillatus & 0,70 & 3,01 & 9,74 & 33,81 \\
Pomacentrus philippinus & 0,89 & 2,31 & 7,47 & 41,29 \\
Pomacentrus moluccensis & 1,20 & 2,13 & 6,86 & 48,15 \\
Chaetodon octofasciatus & 1,34 & 1,90 & 6,12 & 54,27 \\
Amblyglyphidodon curacao & 1,11 & 1,64 & 5,30 & 59,57 \\
Neoglyphidodon melas & 1,02 & 1,31 & 4,23 & 63,80 \\
Thalassoma lunare & 0,81 & 1,21 & 3,91 & 67,71 \\
Chromis viridis & 1,12 & 1,13 & 3,64 & 71,35 \\
10 m, average similarity: 45,70 & & & & \\
Pomacentrus alexanderae & 5,01 & 12,72 & 27,84 & 27,84 \\
Dischistodus prosopotaenia & 1,51 & 4,18 & 9,14 & 36,97 \\
Pomacentrus simsiang & 1,20 & 3,17 & 6,93 & 43,90 \\
Cheilinus fasciatus & 1,59 & 2,79 & 6,10 & 50,00 \\
Pomacentrus philippinus & 1,01 & 2,65 & 5,80 & 55,80 \\
Halichoeres melanurus & 0,71 & 2,51 & 5,50 & 61,30 \\
Thalassoma lunare & 0,82 & 1,82 & 3,99 & 65,29 \\
Pomacentrus nagasakiensis & 1,10 & 1,70 & 3,73 & 69,02 \\
Pomacentrus moluccensis & 0,70 & 1,51 & 3,31 & 72,33 \\
Chromis lepidolepis & 0,94 & 1,51 & 3,30 & 75,63 \\
\hline
\end{tabular}

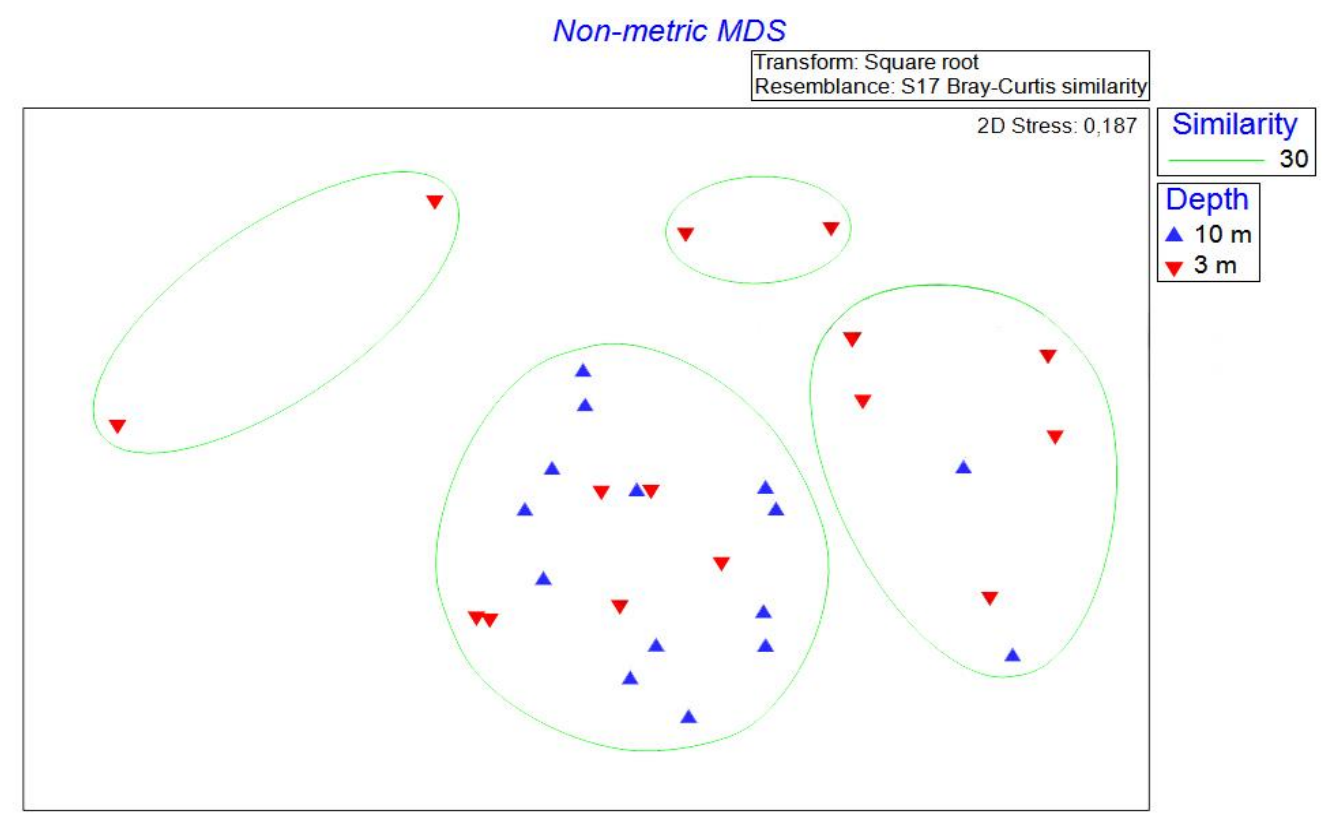

Figure 4. MDS plot of fish communities at the Pramuka Island, showing among pattern of association among 17 species based on abundance 
Several factors may have contributed to the reef fish distribution. Food sources and various trophic categories distinguish the fish composition and related to behavior and habitat (Fre'de'rich et al.,, 2009; Madduppa et al., 2012b). Vertical migration of zooplankton and phytoplankton during the day influence the feeding behavior of reef fish (Williamson et al., 2011). Zooplankton likely migrates to surface at afternoon and descend to deeper water at dawn (van Haren \& Compton, 2013) while the phytoplankton likely migrates to surface at dawn and return back to deeper water at dusk (Gerbersdorf \& Schubert, 2011). Variation of coral communities across the depths significantly affect reef fish density (Lison de Loma et al., 2011). However, the percentage of hard coral cover at the depth of $3 \mathrm{~m}$ was dominantly low. According to Macdonald et al., (2016), shallow water represents where the reef fish distribution strongly related to the availability of live coral.

\section{Conclusion}

The present study results showed that the abundance and species richness of reef fishes around Pramuka Island were higher at $10 \mathrm{~m}$ depth and reef fish assemblages were clustered in both of two depth, although several transects in $3 \mathrm{~m}$ were separated. Pomacentridae and their member Pomacentrus alexanderae was the most dominant family and the most abundant species, respectively. Omnivorous was dominant fish trophic categories. Reef fish composition around Pramuka Island seems to be linked to habitat condition such as coral reefs.

\section{Acknowledgements}

The authors would like to thanks the members of Fisheries Diving Club, Bogor Agricultural University (FDC-IPB), in particular to the CORALATION III team members (Karizma Fahlevy, Ahmad Eko Suprianto, Wedi Andika, Firsta Kusuma, Mas Irfanto, Nadya Jeny) for their effort in field data collection and analysis, and to Dr. Ir. Budhi Hascaryo Iskandar, M.Si. and Uus Abdul Kudus, S.Pi., M.Si as the instructor of FDC-IPB for their advice in the survey design. This research supported by Bogor Agricultural University, the Western fleet of Indonesian Republic (ARMABAR), Kepulauan Seribu National Park (TnKPS), PKSPL-IPB, TERANGI Foundation, Wildlife Conservation Society, Department of Marine, Agriculture, and Food Security, Jakarta that are allowing the team to contribute to the management of Seribu Islands National Park, Pramuka Island regions.

\section{References}

Alvarez-Filip, L., J.A. Gill, and N.K. Dulvy . 2011. Complex reef architecture supports more small-bodied fishes and longer food chains on Caribbean reefs. Ecosphere, 2(10): 118 .

Baum, G., H.I. Januar, S.C.A. Ferse, and A. Kunzmann . 2015. Local and Regional Impacts of Pollution on Coral Reefs along the Thousand Islands North of the Megacity Jakarta, Indonesia. PLoS ONE, 10(9): e0138271.

Benfield, S., L. Bacter, H.M. Guzman, and J.M. Mair. 2008. A comparison of coral reef and coral community fish assemblages in Pacific Panama and environmental factors governing their structure. Journal of the Marine Biological Association of the United Kingdom, 88(7): 1331-1341. 
Bruno, J.F., and E.R Selig. 2007. Regional decline of coral cover in the indo-pacific: timing, extent, and subregional comparisons. PLOS ONE, 2(8):e711.

Burgess, S.C., K. Osborne, and M.J. Caley. 2010. Similar regional effects among local habitats on the structure of tropical reef fish and coral communities. Global Ecology and Biogeography, 19: 363-375.

Dinsdale, E.A., and V.J. Harriott. 2004. Assessing anchor damage on coral reefs: a case study in the selection of environmental indicators. Environmental Management, 33:126-139.

Dixson, D.L., G.P. Jones, P.L. Munday, M.S. Pratchett, M. Srinivasan, S. Planes, and S.R. Thorrold. 2011. Terrestrial chemical cues help coral reef fish larvae locate settlement habitat surrounding islands. Ecology and Evolution, 1:586-595.

Edrus, I.N., and M. Abrar. 2016. Diversity of reef fish fungsional groups in terms of coral reef resiliences. Indonesian Fisheries Research Journal, 22(2):109-122.

English, S., C. Wilkinson, and V. Baker. 1997. Survey Manual for Tropical Marine Resources. 2nd ed. Australian Institute of Marine Science. Australia (AIMS), Townsville.

Estradivari, M. Syahrir, N. Susilo, S. Yusri, and S. Timotius. 2007. Jakarta coral reefs: Long-term monitoring of the Kepulauan Seribu coral reefs (2004-2005). Yayasan Terangi ,Jakarta. $87 \mathrm{p}$.

Fahlevy, K., S. Khodijah, I.A. Nasrullah, R. Fathihatunnisa, B. Subhan, and H.H. Madduppa .2017. Site and depth influence on reef structure and composition in Seribu Islands, Jakarta. AJAS, 2(1):28-38. Doi:10.13170/ajas2.1.8212.

Fauzi, A., E.A. Buchary. 2002. A socioeconomic perspective of environmental degradation at Kepulauan Seribu Marine National Park, Indonesia. Coastal Management. 30: 167-181.

Fenner, D. 2012. Challenges for Managing Fisheries on Diverse Coral Reefs. Diversity. 4:105-160.

Fre'de'rich, B., G. Fabri, G. Lepoint, P. Vandewalle, and E. Parmentier. 2009. Trophic niches of thirteen damselfishes (Pomacentridae) at the Grand Re'cif of Toliara, Madagascar. Ichthyological Research, 56:10-17.

Friedlander, A.M., Y. Golbuu, E. Ballesteros, J.E. Caselle, M. Gouezo, D. Olsudong, and E. Sala. 2017. Size, age, and habitat determine effectiveness of Palau's Marine Protected Areas. PLoS ONE, 12(3): e0174787.

Froese, R., and D. Pauly. 2010. FishBase. World Wide Web electronic publication. www.fishbase.org.

Gerbersdorf, S.U., and H. Schubert. 2011. Vertical migration of phytoplankton in coastal waters with different UVR transparency. Environmental Sciences Europe, 23:36.

Graham, N.A.J., T.D. Ainsworth, A.H. Baird, N.C. Ban, and L.K. Bay. 2011. From microbes to people: Tractable benefits of no-take areas for coral reefs. Oceanography and Marine Biology: An Annual Review, 49: 105-136.

Gratwicke, B., and M. Speight. 2005. The relationship between fish species richness, abundance and habitat complexity in a range of shallow tropical marine. Journal of Fish Biology, 66(1): 650-667.

Hariri, M.S.B. 2012. The Present Status of the Red Sea Coral Reefs between Haql and Yanbu, Saudi Arabia. Life Science Journal, 9(4): 3852-2859. 
Harter, S.L., M.M. Ribera, A.N. Shepard, and J.K. Reed. 2009. Assessment of fish populations and habitat on Oculina Bank, a deep-sea coral marine protected area off eastern Florida. Fisheries Bulletin, 107:195-206.

Iskandar, D. 2011. Bycatch Analyses of Pot Operated In Coral Reef Waters of Seribu Islands. Jurnal Saintek Perikanan. 6(2): $31-37$.

Komyakova, V., P.L. Munday, and G.P. Jones. 2013. Relative Importance of Coral Cover, Habitat Complexity and Diversity in Determining the Structure of Reef Fish Communities. PLoS ONE, 8(12): e83178.

Lane, D.R., R.C. Ready, R.W. Buddemeier, J.A. Martinich, K.C. Shouse, and C.W. Wobus . 2013. Quantifying and Valuing Potential Climate Change Impacts on Coral Reefs in the United States: Comparison of Two Scenarios. PLoS ONE, 8(12): e82579.

Lison de Loma, T., P. Chabanet, J. Ferraris, R. Galzin, and M. Harmelin-Vivien. 2011. Long-term spatiotemporal variations in coral-reef community structure and fishing at a South Pacific Atoll. Aquatic Living Resource. 22, 281-290.

Litsios, G., L. Pellissier, F. Forest, C. Lexer, P.B. Pearman, N.E. Zimmermann, and N. Salamin. 2012. Trophic specialization influences the rate of environmental niche evolution in damselfishes (Pomacentridae). Proceedings of the Royal Society BBiological Sciences. 279: 3662-3669

Luiz, O.J., T.C. Mendes, D.R. Barneche, C.G.W. Ferreira, R. Noguchi, R.C. Villaça, C.A. Rangel, J.L. Gasparini, and C.E.L. Ferreira. 2015. Community structure of reef fishes on a remote oceanic island (St. Peter and St. Paul's Archipelago, equatorial Atlantic): the relative influence of abiotic and biotic variables. Marine and Freshwater Research. doi: 10.1071/MF14150

Madduppa, H.H., S.B. Agus, A.R. Farhan, D. Suhendra, and B. Subhan. 2012a. Fish biodiversity in coral reefs and lagoon at the Maratua Island, East Kalimantan. Biodiversitas, 13 (3): 145-150.

Madduppa, H.H., S.C.A. Ferse, U. Aktani, and H.W. Palm. 2012b. Seasonal trends and fish-habitat associations around Pari Island, Indonesia: setting a baseline for environmental monitoring. Environmental Biology of Fishes, 95:383-398.

Madduppa, H.H., Subhan, B., Suparyani, E., Siregar, A.M., Arafat, D., Tarigan, S.A., Alimuddin, Khairudi, D., Rahmawati, F., Bramandito, A. 2013. Dynamics of fish diversity across an environmental gradient in the Seribu Islands reefs off Jakarta. Biodiversitas, 14(1):17-24.

Madduppa, H.H., S.C.A. Ferse, N.P. Zamani, B. Subhan, and U. Aktani. 2014. Feeding behavior and diet of the eight-banded butterflyfish Chaetodon octofasciatus in the Thousand Islands, Indonesia. Environmental Biology of Fishes, 01/2014; 97(12)., DOI:10.1007/s10641-014-0225-z.

Magurran, A.E. 1988. Ecological diversity and its measurement. Princeton University Press, Princeton.

McClanahan, T.R, A.H. Baird, P.A. Marshall, and M.A. Toscano. 2004. Comparing bleaching and mortality responses of hard corals between southern Kenya and the Great Barrier Reef, Australia. Marine Pollution Bulletin, 48:327-335.

McKenna, S.A., and P. Etnoyer . 2010. Rapid Assessment of Stony Coral Richness and Condition on Saba Bank, Netherlands Antilles. PLoS ONE, 5(5): e10749.

Messmer, V., G.P. Jones, P.L. Munday, S.J. Holbrook, R.J. Schmitt, and A.J. Brooks. 2011. Habitat biodiversity as a determinant of fish community structure on coral reefs. Ecology, 92(12):2285-2298. 
Nakamura, Y., D.A. Feary, M. Kanda, and K. Yamaoka. 2013. Tropical Fishes Dominate Temperate Reef Fish Communities within Western Japan. PLoS ONE, 8(12):e81107.

Nanami, A., M. Nishihira, T. Suzuki, and H. Yokochi. 2005. Species-specific habitat distribution of coral reef fish assemblages in relation to habitat characteristics in an Okinawan coral reef. Environ Biol Fishes, 72(1):55-65.

Pendleton L., A. Comte, C. Langdon, J.A. Ekstrom, S.R. Cooley, L. Suatoni, M.W. Beck, L.M. Brander, L. Burke, J.E. Cinner, C. Doherty, P.E.T. Edwards, Gledhill, L.Q. Jiang, R.J. van Hooidonk, L. Teh, G.G. Waldbusser, and J, Ritter. 2016. Coral Reefs and People in a High-CO2 World: Where Can Science Make a Difference to People?. PLoS ONE, 11(11): e0164699.

Randall, J.E., G.R. Allen, and R. Steene. 1990. Fishes of the Great Barrier Reef and Coral Sea. Crawford House Press, Bathurst, NSW, Australia.

Riegl, B.M., C.R.C. Sheppard, and S.J. Purkis. 2012. Human Impact on Atolls Leads to Coral Loss and Community Homogenisation: A Modeling Study. PLoSONE, 7(6): e36921.

Santoso, A.D. 2010. Kondisi terumbu karang di Pulau Karang Congkak Kepulauan Seribu. Jurnal Hidrosfir Indonesia, 5(2): 73-78.

Setyawan, E., S. Yusri, and S. Timotius S (ed.). 2011. Coral reefs of Jakarta: long-term observation of coral reefs of Seribu Islands 2005- 2009. Yayasan Terangi, Jakarta. vi+102 p.

Sjafrie, N.D.M. 2009. Coral reef condition and others organisms in Selat Nasik subdistrict water Belitung district in period 2007-2008. Jurnal Perikanan, 11(2):150-156.

Subhan, B., D. Arafat, G. Andono, Mursalin, H. Madduppa. 2008. Study on substrate cover in coral reefs region in Karang Beras, Air, Panggang, and Pramuka Island, Seribu Archipelago, Special Capital Region, Jakarta. Proceedings of the seminar and the 2008 National Conference on Waters Utilization of Aquatic Resources Sector. Fakultas Perikanan dan Ilmu Kelautan Universitas Brawijaya Malang, Malang. 2: 185-189.

Subhan, B., F. Rahmawati, D. Arafat, N.A. Bayu. 2011. Coral health condition of family Fungiidae on Pramuka Island, Seribu Islands. Jurnal Teknologi Perikanan dan Kelautan, 2 (1) : 41-50.

van Haren, H., and T.J. Compton. 2013. Diel Vertical Migration in Deep Sea Plankton Is Finely Tuned to Latitudinal and Seasonal Day Length. PLoS ONE, 8(5):e64435.s

Zamani, N.P., Y. Wardiatno, and R. Nggajo. 2011. Development Strategy of Yellow Tail Fusilier Fish (Caesio cuning) Resources Management on Coral Ecosystem in the Seribu Islands. Jurnal Saintek Perikanan, 6(2): 38-51.

Zamani, N.P., and H.H. Madduppa. 2011. A standard criteria for assessing the health of coral reefs: implication for management and conservation. J. of Indonesia Coral Reefs 1 (2), 137-146 